Commonplace • Series 1.3: Global Transition to Open

\title{
Between Two Strategists: A \\ Conversation between \\ Collections and Scholarly \\ Sharing at The Ohio State \\ University Libraries
}

Gene R. Springs, Maureen P. Walsh

Published on: Nov 16, 2021

DOI: $10.21428 / 6 \mathrm{ffd} 8432 . f 2404591$

License: Creative Commons Attribution 4.0 International License (CC-BY 4.0). 


\section{Prologue}

Bridging a traditional organizational divide between collections and scholarly communications, we are the co-leaders of University Libraries' Transforming the Scholarly Publishing Economy strategic initiative. We created a plan and set of priorities to inform and motivate decision-making around directing funds away from paywall subscription models and toward Open Access publishing. Our principles and roadmaps inform our collection strategy, while we also work to apply our equity values of advancing diversity, inclusivity, access, and social justice to scholarly collection building. Our broader goals include educating, informing, and building partnerships with stakeholders across campus and our consortia to support actions that transform publishing economics, expanding avenues of Open Access to advance Ohio State research, and focusing our analytics capabilities to inform negotiations and monitor the impacts of new agreements. Our current transformative and transitional agreements include partnerships with Taylor \& Francis, the Royal Society, and the Public Library of Science (PLOS). University Libraries is currently working on several potential new transformative agreements as an institution and as a consortial partner.

\section{Discussion}

\section{How do your program areas fit into the organizational structure of University Libraries?}

Maureen: Scholarly Sharing and Collections Strategy are two of five program areas within the Content and Access division and as the strategists, Gene and I report to the same Associate Dean. I have been with University Libraries for the past fifteen and half years, and although we have re-organized a few times, my work has remained in 
scholarly communications. Scholarly Sharing as a program area supports Ohio State faculty, staff, researchers, and students as they create, publish, and share their scholarly work. We promote new models for sharing and disseminating scholarly works to advance research, creative expression, teaching and learning. The program area

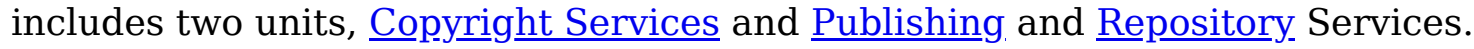

Gene: I came to Ohio State in 2014 as the Business Librarian, part of the Research and Education division. In 2016 I had an opportunity to serve as the interim Collections Strategist following a colleague's departure and then was permanently appointed to the position in 2017. In this position I manage the Libraries' materials budget. Collections Strategy as a program area includes managing all collections building activities, collections analytics, print collection management, and providing support for subject liaisons who manage materials budget funds.

\section{How did you interact with each other's program areas prior to the strategic initiative?}

Maureen: Prior to our initiative which began in early 2019, we interacted as fellow program area heads and colleagues at an administrative level in the division. We served on committees together and our functional areas intersected, especially Copyright Services and Collections Strategy, but as the Strategist, I did not have regular occasion to work directly with Gene.

Gene: Since our program areas had mostly differentiated goals, Maureen and I did not work together much in functional capacities prior to the initiative, but more based on our administrative roles in the organization. Now that we are working closely together on the initiative, we have some shared annual goals to base our work around. I know that this shared work has been really beneficial for me.

\section{What excites you the most about the initiative?}

Gene: Well, there is so much to choose from! But I think one aspect that resonates with me the most is contributing to what will hopefully result in a flip of the marketplace from the current subscription model to a sustainable Open Access model. One in which libraries are not just customers but are partners. It's highly aspirational, but there seem to be some indications already that progress is being made, 
particularly with our pilot agreements and also with what publishers are more proactively putting out in the community.

Maureen: It has been really rewarding to bring together scholarly sharing and collections strategy. Working together - the way we have been able to move the needle - I don't think our program areas working separately could have done as much. Looking at what might be possible in terms of operationalizing this work beyond the initiative is exciting to me. We've done a lot of grassroots work in scholarly sharing over the past twenty years. Our Diamond Open Access publishing program is its fourteenth year, and our institutional repository program is its nineteenth year. We've pushed forward incremental advancements, and with the activation at the campus level now, we have an opportunity to see substantial changes.

\section{Which one of your current publishing agreements under the initiative most excites you?}

Gene: I would choose the Taylor \& Francis Read and Publish agreement. It was University Libraries first Read and Publish agreement; it was also the first of this kind for Taylor \& Francis in North America. This agreement resulted from long-term conversations with Taylor \& Francis about expanding our Read access at scale due to campus-wide demand, dovetailing with the beginning of the initiative and trying to articulate goals toward a more open future. The publishing portfolio of Taylor \& Francis was also intriguing for us in this pilot agreement - would authors from disciplines that have not traditionally published Open Access do so if cost were not a barrier? I think it is great that both University Libraries and Taylor \& Francis are learning a great deal with this agreement.

Maureen: Gene, to follow-on, an exciting aspect of the Taylor \& Francis agreement for me is that it includes their fully Open Access journals. Our goal is to flip the model to have more open content, and not by continuing to pay into a system of double-dipping. I would choose our unlimited pure publish agreement with PLOS. It is wonderful to be able to support an Open Access publisher that has not only been a pioneer, but one that is continually thinking about sustainability and global equity. And to support our authors with a publisher our subject liaisons inquired about the most. There was a clear interest from our researcher community to do something in this space and it is exciting for PLOS to have recognized this and to experiment in this marketplace. This 
was also a terrific opportunity to collaborate with the Health Sciences Library to offer this across the entirety of Ohio State.

Gene: Yes, it's important to note this work occurring across Ohio State's libraries as well. The Health Sciences Library and the Wooster Campus Research Library are key partners in the Taylor \& Francis agreement.

\section{Can you give us an idea of how you work together? What do you understand better now about each other's work?}

Gene: I think one of the greater benefits of the initiative has been working more closely with Maureen. We bring very different strengths to the table, although we have enough similarities that we can speak to each other and understand what the other means. It's been really encouraging to be able to bounce ideas around with each other, be open, honest and critical of the work that we're doing. Also, feeling comfortable to surface where some additional learning needed to be done. For me, I really needed to focus on aspects of Open Access and scholarly communication that I had not really had to do in this role and others I've had.

Maureen: This initiative was an opportunity to bring together two program areas around the same goals and objectives. We were coming to this from different perspectives and experiences. The goals for our functional areas have traditionally had different ideas of outcomes.

I didn't have experience with this kind of publisher negotiation and licensing prior to the initiative and working with Gene, and Anita Foster, our Electronic Resources Officer, has been a learning opportunity. Working with commercial publishers in this way is a different ball game from the functional expertise in my area, but we remain mission driven.

Gene and I meet weekly now to touch base and strategize. We know what we are bringing to the table and, at first, we did not have a common language. We now have a deeper understanding of each other's perspectives, and we have a respect for that, and we allow room for that.

Gene: Before, I was really only seeing things from the perspective of the end customer within the marketplace. We receive an offer from a publisher or vendor, have some opportunity to negotiate cost, license terms, and access that most benefit the Ohio 
State community. Working with Maureen has enabled me to really understand the entirety of scholarly publishing; not just the customer perspective, but also the producer/publisher perspective. Understanding the author/researcher perspective within the scholarly publishing ecosystem and helping propel a move away from just access to the tools to opening up and reconfiguring the toolbox.

Maureen: Gene, that is an interesting point. An important aspect of this collaboration is a focus on the perspective of authors, editors, and scholarly societies. We know what Ohio State is bringing to the table, and who we are doing this for. Certainly, for a more equitable and sustainable marketplace, and for our researchers, for the work that they are doing and the global reach of their scholarship.

When we are looking at the changing landscape of scholarly publishing, we are looking at the infrastructure of scholarly publishing. What we are supporting and what we are perpetuating, and where we can go. And how we interrogate our actions. A foundational aspect of this work is our ongoing learning around diversity, equity, inclusion, accessibility, and social justice.

\section{What do you think a post strategic initiative and/or operationalized scenario will look like?}

Gene: Well, that's the multi-million-dollar question. To a certain degree, I think the strategic-level work will be the same, with Maureen and I establishing priorities and iterating goals as needed. Assuming there is a marketplace shift to Open Access agreements, I would anticipate needing to redefine positions and roles within our program areas, hopefully in alignment with evolving work roles across campus, perhaps in units like the Office of Research.

Maureen: That's an exciting opportunity, Gene, to think about what the program areas might look like in the future if we were to continue to work closely together.

My hope is that we do operationalize this work. What is now for the two of us experimental or pushing the boundaries - thinking of different ways to work together to move this initiative forward. But coming out of this initiative, hopefully, we are changing the marketplace, we are changing the economics of scholarly publishing.

What now might be a pilot or something experimental becomes programmatic; functions that may fall in or across our program areas - modus operandi going 
forward. But let's not forget, always questioned, and continually improved upon.

Gene: Beyond Ohio State, I am curious to see how this work may be operationalized with our consortia, who are piloting transformative agreements as well. One of the great benefits of the initiative collaboration is in seeing the demonstrated impact of contributions from "scholarly communication" to what has traditionally been "collections" work. My experience is this expertise is not just additive to the conversations that are happening in collections groups, but is in and of itself transformative to scale, value, and impact.

\section{What are each of you taking away from the collaboration?}

Gene: My main takeaway is that while some aspects of our work are very different, the initiative made clear an inherent alignment in the aspects of our work that relate to what Ohio State researchers and educators need to best do their work. I think continued collaboration between Maureen and I, and our program areas, will be essential.

Maureen: I had not thought working so closely with the collections strategist - the position, not the person - would be so fruitful. Certainly, ours is a strategic partnership, but it is integral to the work we are doing on some level. Our areas, our normal day-to-day functions, are different. On the strategic level, it is important that Gene and I are aligned. And that we continue to be aligned, going into the future.

Going into this, we each had our pieces of the scholarly publishing landscape. But although there are many similarities, they are different pieces approached in quite different ways. They are staffed in separate ways and have separate goals and objectives. Bringing these together is only stronger for the mission of University Libraries.

\section{Conclusion}

As we continue to explore, the post-pilot world remains unknown. It is clear from our dialogue that the collaboration between the Scholarly Sharing and Collections Strategy program areas, driven by the strategic initiative, has enabled a new kind of work that is beneficial to our units, University Libraries, Ohio State researchers and, ultimately it is hoped, to readers and researchers around the globe. 
